\title{
SOSYAL AĞLAR VE MODERN İNSANIN YALNIZLAŞMASI: COCA- COLA REKLAM ÖRNEĞİ
}

\author{
SOCIAL NETWORKS AND MODERN MAN'S LONELINESS: AN ADVERTISING OF \\ COCA COLA
}

\author{
Eda SEZERER ALBAYRAK ${ }^{1}$
}

\begin{abstract}
$\ddot{O} z$
İnternetin ağlar oluşturarak hayatımızın içine girmesi ve son on yıldır milyarlarca kişi tarafından kullanılması, internet ile mobil iletişimin yakınsamasının bir sonucudur. Her teknoloji, toplumların üzerinde toplumsal ve sosyal açıdan dönüşümler ve değişimler sağlamaktadır. Özellikle iletişim teknolojileri ile beraber, toplumların alışkanlıklarından, yıllardır süregelen kültürlerine, yapılarına, iş yaşamlarına kadar değişimler oluşmaktadır. Modernleşen bireyler geleneksel iletişim biçimlerinden ziyade, parmak dokunuşlarıyla dünya çapında birçok kullanıcıya erişme imkânı sağlayan bir ağ iletişimini tercih etmektedirler. Her türlü iletişimin bu ağlar üzerinden yapılması, sosyal ağların çok fazla tercih edilmesi yeni bir sosyalleşme süreci olarak görülmeye başlanmıştır. Bu süreçle beraber, kişilerin ilişkileri, yaşama biçimleri, iletişimleri farklı bir boyut kazanmıştır. Bireylerin, diğer insanlarla kurdukları iletişim, teknolojiyle aracılanmış bir iletişim biçimine dönüşmüş, zaman ve mekan kavramı ortadan kalkmıştır. Modern insanın, yüz yüze iletişimden ziyade iletişim teknolojileri ve sosyal medya (facebook, twitter, instagram vb.) ile aracılanmıș iletișim biçimini kullanması onları ekrana bağımlı hale getirmektedir. Böylelikle, kalabalık toplumlar çevreleri ve hatta kendilerine yabancılaşmış bireyleri barındırmaktadırlar. $\mathrm{Bu}$ anlık iletişim beraberinde beden dili (jest, mimik) içermeyen, sanal davranış ve sanal duygular içeren bir süreci kapsamaktadır. Sosyal ağlar "manuel" toplumları doğurmuş olup insanların bir araya gelememesine neden olmuştur. Bir araya gelen kişilerin ise belli bir süre sonra çevrelerindeki kișilerle ile aynı ortamdayken "sanal" ortamlarına dönmeyi tercih ettikleri gözlenmektedir. Bu çalışma ile toplulukların içinde yaşayan "yalnız" kişilerin sosyal ağlar aracılığıyla sosyalleşmeyi tercih etmeleri ve teknoloji sayesinde modernleşen fakat bir o kadar yabancılaşmış topluma Coca Cola'nın "Sosyal Medya" temalı reklam filmi penceresinden göstergebilimsel çözümleme ile eleştirel bir bakış açısıyla yaklaşılacaktır.
\end{abstract}

Anahtar Kelimeler: Sosyal Medya, Yalnızlık, Modern İnsan

\begin{abstract}
Having the internet into our lives by creating networks and being used by billions of people over the last ten years is a result of the convergence of internet and mobile communication. Every technology provides societal and social transformations and changings over societies. Along with communication technologies, changes are taking place from the habits of the communities, to the cultures that have been going on for years, to the structures and business life. Modernized individuals prefer a networking approach that allows them to access many users worldwide with their finger touches, rather than traditional forms of communication. Making all kinds of communication over these networks started to be seen as a new process of socialization. Along with this process, people's relationships, ways of living and communication have gained a different dimension. The use of modern human communication by communication technologies and social media (facebook, twitter, instagram etc.) rather than face-to-face communication makes them dependent on the screen. In this way, crowded societies host communities and even alienated individuals. This instant communication includes a process that does not involve body language (gesture, mimic), including virtual behavior and virtual emotion. Digital networks have created "manual" societies so people could not come together because of this. It is observed that those who come together prefer returning to "virtual" environments. With this study, people who live in communities prefer to socialize through social networks, and thanks to the technology, a modernized but so alienated society will be approached from a critical point of view through semiotic analysis of Coca Cola's "Social Media" theme advertising film window.
\end{abstract}

Keywords: Social Media, Loneliness, Modern Men

${ }^{1}$ Dr. Öğr. Üyesi, KTO Karatay Üniversitesi, 


\section{GİRIȘ}

90'lı yıllardan itibaren iletişimin ve internetin gücü ve bilişim sistemlerinde kaydedilen gelişmeler, bizi yeni teknolojik gelişmelerle tanıştırmış ve toplumsal yaşamı farklılığa sürüklemiştir. Teknolojik gelişmeler ve yeni medyanın ortaya çıkışı yeni kullanım alanlarını da beraberinde getirmiştir. Teknolojinin getirdiği bu dönüşüm ile birlikte, toplumsal yaşamın yer aldığı toplumsal mekanların bir önemi kalmamış, iletişim daha çok web ortamlı, zaman ve mekandan bağımsız sanal ortamlarda siberalem iletişim biçimine dönüşmüştür. Günümüz toplumunun hızlı yaşayan kopuk ilişkileri içerisinde insanlar bir sosyal ilişki kurma ya da mevcut olan sosyal ilişkilerini devam ettirme şansını sosyal medya yardımıyla sağlamaktadırlar. Sosyal paylaşım sitelerine mobil ya da sabit, her türlü iletişism araciyla erişebilmek (kişisel bilgisayar, cep telefonu, televizyon) özellikle genç kuşak bireylerinin vakitlerinin önemli bir kısmını sanal evren içerisine geçirmelerine olanak sağlamaktadır. Böylelikle sosyalleşme mekanları zaman içerisinde bir dönüşüm içerisine girmiş ve kişilerarası iletişimin en önemli noktası olan yüz yüze görüşmenin önüne geçerek bir araya gelme gereksinimini ortadan kaldırmıştır.

Modern insanın zaman yönetimi ile ilgili sorunlar yaşadığı günümüzde sosyal paylaşım ağlarının kullanılması bir nebze de olsa bu sorundan uzaklaşılmasını sağlamış ve hayatımızın her alanına sızmayı başarmıştır. Metropol insanları artık her türlü bankacılık, sağlık, eğitim, randevu alma, rezervasyon, ulaşım vb ihtiyaçlarını ekranlarının başından yapabilmekte, bilgiye zaman ve mekan kısıtlaması olmadan, coğrafi engelleri aşarak ulaşabilmektedir. Ancak, ilgili durum zihin ve bedenin uyumunu olumsuz anlamda etkilemekte, zihnimiz tek bir tuş ile verileri sayısal ortama aktarabilmekteyken bedenimiz ise sabit bir şekilde yerinde kalmaktadır. Bu durum ise kişilerin hem sağlık durumlarını hem de insanların ve toplumların iletişimlerini, çevreleriyle olan ilişkilerini, etkileşimlerini ve sosyalleşme süreçlerini ciddi düzeyde etkilemektedir. Modern insanın, yüz yüze iletişimden ziyade iletişim teknolojileri ve sosyal medya ile aracılanmış iletişim biçimini kullanması onları ekrana bağımlı hale getirmektedir. Böylelikle, kalabalık toplumlar çevreleri ve hatta kendilerine yabancılaşmış bireyleri barındırmaktadırlar.

$\mathrm{Bu}$ çalışmada, son yıllarda yapılan teknolojik gelişmeler sonucunda bireylerin kişilerarası iletişimlerinde meydana gelen değişikliklere ve sosyal ağların, gerçek yaşamdaki sosyal yaşamın önüne geçtiği gerçeğine, sanal iletişim, sanal sosyal çevre iletişimi ile bireyleri sınırlandırmasına eleştirel bir pencereden bakılacaktır. Ayrıca, Coca Cola firmasının kalabalık toplumlar içinde yaşayan yalnız bireylere dikkat çekmek amaçlı yayınlamış olduğu "Sosyal Medya" temalı reklam filmi örnek olarak incelenecek ve göstergebilimsel açıdan analizi yapılacaktır.

\section{MODERN TOPLUMLARDA DİJITALLEŞEN BİREYLER}

İnsanoğlu, geçmişten bugüne kadar çağlar boyunca büyük değişimler yaşamış ve toplum bu değişimlere göre şekillenmiştir. İletişim teknolojilerinin insanların hayatlarında yer alması ile beraber toplumların iş yaşamlarından kültürlerine, eğitim sistemlerinden alışkanlıklarına kadar her ögenin tamamıyla değiştiği vurgulanmaktadır. Özellikle modernizmle beraber alışılagelmiş geleneksel yapıdan uzaklaşılmış toplum düzeni modernizme göre değişiklikler göstermiştir. Giddens (2012:12) modernizmin, düşünsel, ekonomik, siyasi, teknolojik ve sosyal alanlar gibi birçok alanda büyük dönüşümlere neden olduğunu, modernliğin getirileri rasyonalite ile düşünsel alanda; kapitalizm ile ekonomik alanda; ulus-devlet ile siyasal alanda; sanayileşme ile teknolojik alanda; kentler ile de sosyal alanda hissedildiğini ve modern olmakla, kendini geçmişin yerine ikame eden bir dünya, günümüz toplumunun tarihini karakterize eden geleneklere, adetlere, alışkanlıklara, rutinlere, beklentilere ve inançlara bağlı olmayan bir toplum olarak sosyal bir düzenlemesi olduğunu 
söyler. Billington vd (Billington, Hockey, Strawbridge, 1998:178) göre de modernleşme süreci, insanların yaşadığı sosyal alanın belirgin bir şekilde genişlemesine neden olmuştur. Bireyler; aile, arkadaş, iş mahalle gibi farklı çevrelerin bir parçası olarak yaşantılarını sürdürmektedirler. Bütün bu sosyal ilişkiler içerisinde birey, farklı sosyal pozisyonlar alır ve kendilerinden beklenen ilgili rolleri gerçekleştirir. Tüm bu değişen durum içerisindeki işleyiş sosyal yeterlilik gerektirmektedir. Fiziksel çevredeki değişimler, bilimsel ve teknolojik yenilikler, çalışma ve serbest zamanın yeniden yapılandırılması, küreselleşme ve kapitalizmin etkileri, gündelik yaşantılarımızda önemli değişimler yaşanmasına neden olmaktadır. Medyanın dijitalleşmesinin bir sonucu olarak, akrabalık ve arkadaşlık ilişkileri, aktivitelere ve hobilere katılım, sosyal rollerin gündelik yaşama geçirilmesi ve sosyal ilişki kurma biçimlerini olumsuz anlamda etkilemiştir. Değişimi çok hızlı bir şeklide beraberinde getiren modernizm, en büyük ve hızlı değişimi ise teknolojik gelişmeler tarafından gözler önüne sermiştir.

Günümüz dünyası insanların hayal gücünü zorlayacak dijital değişimlere şahit olmakta ve modern insan bu değişimin içinde yaşamaktadır. Yaşanılan dijital dünyada zaman-mekan ve insan ilişkilerinde devrimler olmakta ve bireyler, bu farklı ve anlaşılmasında güçlük çekilen dijital dünyaya ayak uydurmaya çalışmaktadırlar. Küreselleşme sürecinin beraberinde getirdiği teknolojik yenilikler, binlerce kilometrelik mesafelerin çok kısa sürelerde aşılmasını, farklı kıtalarda yaşayan insanların aynı anda birbirlerini internet teknolojileri yardımıyla bulundukları yerden tele-konferans aracılığıyla görüşebilmelerini sağlamakta ve böylelikle mekanın artık önemini yitirdiği gibi bir izlenim ortaya çıkmaktadır (Yılmaz, 2008:155). İnternet teknolojisi ile beraber sınırlar ortadan kalkmış, zaman kavramı bağımsızlaşmış ve sanal dünya devreye girmiştir (Mercan, 2010:4). Bilgi, zamandan bağımsız olarak artık çok hızlı bir şekilde ilerlemekte ve Harvey'in "zaman-mekan sıkışması" olarak adlandırılan durum ortaya çıkmaktadır. Bireyler artık diğer ülkelerden mekan değişikliği yapmadan eğitim programlarına katılabilmekte, ödemelerini, market alışverişlerini, randevularını "tek tuş"la sanal ekranlar aracılığıyla yapabilmektedirler. Mekanın önemi kalmamakla beraber, zaman mekanın önüne geçmekte ve insanlar 1şık hızıyla enformasyona ulaşabilmektedirler. Bunun sonucunda, insanlar ekran teknolojilerinin sunduğu dünyayı bir an olsun kaçırmadan takip etmekte ve izlemekte olup kendilerinin olmayan bir sanal dünyada yaşamaktadırlar. İnsanların zorunlu veya serbest tüm zamanları birbirine karışmış durumdadır (Çizmeci, 2015:84). Bu bağlamda, oluşan bu devrim ve değişiklikler kişilerin yalnızlaşma ve yabancılaşma sürecini yaşamalarına sebep olmaktadır. Aynı zamanda, günümüzde, sosyal ağlar insanların gündelik hayatlarında olduğu kadar, sanal ortamda sürdürdükleri sanal yaşamları açısından da önemli bir faktördür. Artan bireyselleşme, toplumları, toplumsal parçalanma tehlikesiyle karşı karşıya bırakmaktadır. Bireyselleşme ve küreselleşme, aile, eğitim, iş, sağlık, yaşam ortamları vb. olmak üzere çeşitli alanlarda heterojenlik meydana getirmektedir. Modern toplum yapılarında farklı geçmişlere ve yaşam tarzlarına sahip sosyal ve kültürel yapılar bir arada bulunmaktadır. Toplumsal yaşam için ortak bir temel bulmak ve tüm sosyal gruplar için kabul edilebilir olan kurallar ve normlar üzerinde fikir birliğine ulaşmak gittikçe güçleşmektedir.

\section{3. İNTERNET VE SOSYAL AĞLAR KAPSAMINDA KISŞILERIN YABANCILAŞMA VE YALNIZLAŞMALARI}

Yeni Medya teknolojileri, bireylerin gündelik işlemlerini çok kısa ve kolay şekilde bitirebilmelerini sağlamakta ve insanların sadece parmak uçlarını kullanarak çevresiyle iletişim kurmalarına da olanak vermektedir (Engin, 2012:3-6). Küçüksaraç (2014:63), yeni medyayı "geleneksel medyadan farklı olarak, dijital kodlama sistemine temellenen, iletişim sürecinin aktörleri arasında eş anlı ve çok yoğun kapasitede, yüksek hızda karşılıklı ve çok katmanlı etkileşimin gerçekleştiği multimedya biçimselliğine sahip iletişim araçları olarak", 
Eldeniz (2010:18) ise "sayısallaşan, bilgisayarlarla üretilen ve yayınlanan ağlar üzerinde gezen bir medya" olarak tanımlamıştır. Medyayı yeniden bir kalıp içine alan ve yeniden şekillendiren küreselleşme bilgiyi bireyler ve kurumlar için daha anlamlı ve değerli hale getirmektedir. Küreselleşmenin de sonucu olarak "hızlı öğrenme, hızlı üretme ve hızlı tüketme" gibi özelliklerini içinde barındıran dokunmatik cihazlar sayesinde bireyler parmak uçlarıyla tüm dünyaya bağlanabilmekte, dokunmatik bireylerden oluşan dokunmatik bir jenerasyonu ortaya çıkarmaktadır (Yengin, 2012:36). David Harvey ise yeni medya teknolojileriyle çevrili günümüz toplumuna "parmak ucu toplumu" adını vermiştir (Harvey, 1999:86-140). Öyle ki, Castell, her şeyin internete bağl1 olduğu günümüz toplumunda internete bağlı olmadan yaşamanın pek de mümkün olmadığını, kişilerin toplumun dışında kalmamak için internete bağlanmalarının gerektiğini düşünmektedir (akt. Kaya, 2013:162).

Yeni Medya egemenliğinde mesafe sınırını ortadan kaldırarak, yüz yüze iletişim olmaksızın kullanıcıları arasındaki paylaşım ve sosyal iletişime fırsat veren ve bu özellikleri sayesinde kendine özgü bir yer bulan platformlar sosyal medya ve sosyal ağlardır (Torlak ve Ay 2014:83-94). Sosyal medya, "web siteleri, bloglar, podcast, mesaj panoları, içerik paylaşım siteleri ve çok yaygın bir şekilde kullanılmakta olan sosyal ağ siteleri” (Kuşay, 2010:61) gibi mecraları içermekte ve kullanıcıların, çevrimiçi sosyal topluluklar içerisinde birbirleriyle iletişim kurmalarını, ortak ilgi alanlarına veya ortak özelliklere sahip diğer kullanıcılara ulaşarak onlarla iletişim kurabilmeyi sağlamakta, aynı zamanda da kullanıcıların fotoğraflarını, dosyalarını, kişisel çalışmalarını ve bilgilerini internette yayınlanmasına ve hatta çevrimiçi organizasyonlar düzenlenmesine de yardımcı olmaktadır (Deperoğlu ve Köse, 2010:18). "Sosyal ağlar", günümüzde yeni medya kullanıcılarının en çok zaman geçirdiği yerler olan sosyal medyanın son ve en önemli mecralarıdır. Elison ve Boyd (2013:7)'a göre sosyal medya, katılımciların

1) Arkadaşlarını halka açık bir biçimde paylaşabildikleri

2) Kullanıcıların kendisi, diğer kullanıcılar ve sistem tarafından sağlanan verilerden oluşan kişiye özel profillere sahip olabildiği

3) Sitedeki bağlantıları tarafından sağlanan kullanıcı odaklı içerik akışıyla etkileşebildiği ya da bunları tüketebildiği, üretebildiği bir "ağlaştırılmış iletişim platformu"dur.

James Lull'ın geliştirdiği “Doyum Modeli”ne göre insanlar sosyal medyayı farklı ihtiyaçları sağlamak için, insan ilişkilerinde ortak deneyimleri paylaşmak, insan ilişkilerini geliştirmek için kullanmaktadırlar (Giddens, 2012:656).

Sosyal paylaşım ağlarının çok fazla tercih edilerek sınırlarını genişletmiş olması ile birlikte internet bağımlılığı sosyal medya bağımlılığına dönüşmeye başlamıştır (Cabral, 2011:6). Günümüzde internet kullanıcıları, kendilerine özgü profiller oluşturabildikleri Twitter, MySpace, Facebook gibi sosyal paylaşım ağlarına yoğun ilgi göstermektedir böylelikle internet ortamından uzaklaşmaları zorlaşmaktadır. Mobil telefonlarında sosyal paylaşım ağlarını ve internete yönelik uygulamaları desteklemesiyle beraber bu durumu daha da perçinlemiş ve kullanıcılar bu paylaşım ağlarında uzun vakit harcamaya mahkum olmuşlardır (Şenormanc1 v.d.,2010:261). İstatistiklere göre dünyada 232 milyon Twitter kullanıcısı bulunurken, 2016 verilerine göre Türkiye'de kullanıcı sayısının ise 46,3 milyon'dur. İlgili kullanıcıların 36 milyonu sosyal medyaya mobil cihazlardan ulaşılırken, 42 milyonu ise sosyal medyada aktif olarak yer almaktadır. Türkiye' de $\% 32$ ile en çok kullanılan sosyal medya platformu Facebook iken, Facebook'u \%24 ile Whatsapp, \%20 ile Facebook Messenger, \%17 ile Twitter, \%16 ile Instagram izlemektedir (Avc1, 2017:4). Günümüzde internet erişimi teknolojinin ilerlemesi ile akıllı cep telefonları ve taşınabilir bilgisayarlar aracılığıyla kolaylıkla gerçekleşebildiği için insanlar istedikleri yerde ve istedikleri zaman 
aralıklarında alışverişten arkadaş/eş bulabilme, e-posta kontrol etmekten haber akışlarına ulaşabilme gibi faaliyetlerini yerine getirebilmektedirler. Bu bağlamda internet, girip çıkılan bir yerin aksine her zaman içinde olunan bir yere dönüşmüştür (Özkan, 2014:244-246).

Scott Wallsten'a (2013:25-26) göre, serbest zamanda internet kullanımının süresi, dijital ağlar üzerinde yapılacak aktiviteler çoğaldıkça artmaktadır. Wallsten'a göre, internet kullanımı, uyku ve çalışma zamanından çalmakta, gençlerin eğitimle ile ilgili faaliyetlerini olumsuz olarak etkilemektedir. Ülkemizde 15 yaş ve üstü toplam 1.8 milyon kişinin internet kullandığ 1 ve ayda ortalama 544 milyon saat vakit geçirildiği ve kişi başına aylık 30 saat bir internet kullanımının olduğu düşünülürse, bu gerçek gençlerin ve çocukların bilgi edinme ve bilgi aktarma ihtiyaçlarını nasıl temin ettikleri gibi sorular akla gelmektedir (comScore, 2012). Gentile ve Walsh (2002:163) çalışmalarında, yeni medya teknolojilerinin gün geçtikçe sınırlarını genişlettiğini ve bunun sonucunda ise yetişkinlerin çok daha az etkinliğe katıldıklarını, daha az gazete okudukları ve arkadaşları ve ailelerine ise çok daha az vakit ayırdıklarını ortaya koymuşlardır. 12-17 yaş aralığındaki gençlerin neredeyse \%93'ünün günün büyük bir kısmında sosyal ağ sitelerini kullandığı ortaya konulmaktayken gençlerin yaşıtları ile iletişimlerini büyük oranda sosyal ağları kullanarak yaptıkları sunulmuştur (Huston ve Ripke, 2006:37, Lauricella ve Cingel, 2014:13). Yine yapılan araştırmalarda yoğun bir şekilde internet uygulamalarını kullanan bireylerin sosyal ağlarda görüştükleri kişilerin sayısı ile yüz yüze iletişimde görüştükleri kişilerin sayısı karşılaştırıldığında, yüz yüze iletişim kuran kişilerin sayısının sosyal ağlarda görüşülen kişi sayısının yarısına geldiği görülmektedir (comScore, 2012). İşte bu duruma bir örnek teşkil eden bir araştırmanın sonucunda 18 yaşındaki bir kişinin sosyal paylaşım ağları ile ilgili sözleri şu şekildedir: "Ben bir yıldır sanal ortamda arkadaşlarımla konuşuyorum. İyi bir sohbet grubumuz var ve yedi kişiyiz. Bazen buluşuyoruz. İlk buluşmamız çok ilginç oldu. Kimse kimseyle konuşamadı. Bir internet kafede buluşmuştuk. Baktık olmuyor, hepimiz bir bilgisayarın başına gittik. Aynı mekanda olmamıza rağmen, chat yaparak konuşmaya başladık. Gülüyoruz, birbirimizin güldüğünü duyuyoruz, ama bilgisayarda gülme işareti yapıyoruz haberleşmek için" (Karaoğlu, 2000:16). İşte böylece, insanlar; sanal dünyada karakterlere, sosyal ağlarda profillere, cep telefonlara sözcükler ve duygu belirten küçük imgelere dönüşmüştür. $\mathrm{Bu}$ bağlamda, robotlarla iletişimimiz artmışken, insanlarla ilişkilerimiz azalmıştır (Turkle, 2010:37).

İnternet teknolojisi, fiziksel dünyanın mekânsal, bedensel ve zamansal sınırlarından bağımsız bir alan kurgusu üzerine sanal dünyayı yaratmıştır. Böylelikle, evler, işyerleri ve hatta yaşam sanallaşmaktadır yani insanlar sanal yaşamlarının içinde yaşamadıkları halde "yaşarmış gibi" davranmaktadırlar. Sanallık "olmadığı halde, varmış gibi" bir kavramı ifade etmektedir (Tutar, 2007:135). Bireyler artık ekranlarının başında oturarak sanal sokaklarda komutlarla yön vererek özgürce dolaşabilmekte, oyunlar oynayabilmekte hatta alışverişlerini bile yapabilmektedirler. Eğlence ve iletişim amaçlı internet kullanımı sosyal medya vasıtasıyla sınırlarını genişletmektedir. Facebook birçok oyunu içerisinde bulunduran geniş sosyal paylaşım ağlarından biridir. Sosyal paylaşım ağlarına kullanıcıların bağımlılık derecesinde vakit geçirmelerinin bir nedeni de çevrimiçi oynanan oyunlardır. Farm Ville 2, Cady Crush Saga, Diamond Dash, Coater Ville, Texas HoldEm Poker gibi oyunlar Facebook üzerinden oynanan oyunlar arasında yer almaktadır. Eğlenmek, hayattan uzaklaşmak amaçlı oynanan ilgili oyunlar, kişileri sosyal medya ağlarına bağımlı hale getirebilmektedir (http://optimiseblog.co.uk/a-2013-social-media-report/) Araştırmalara göre, sanal gerçeklik beraberinde milyonları sürükleyen sosyal ağlarda oynanan çevrimiçi oyunları getirmekle kalmayıp sadece çocuklar ve gençleri değil aynı zamanda yetişkinleri de olumsuz yönde etkilemektedirler. Bireyler, 24 saat boyunca oynanan oyunları, gelişmeleri takip edebilmek, diğer oyunculardan geri kalmama amaciyla, sürekli oynamak hevesinde olmaktadırlar. 
Böylelikle, ekran başında en az 15 saat geçiren bireylere bu süre gayet normal gelmektedir. $\mathrm{Bu}$ durum ise, ailesini, arkadaşlarını, derslerini, işlerini ve hatta günlük ihtiyaçlarını ihmal eden içine kapanık bireyleri yaratmaktadır (http://www.arem.gov.tr/yayin/internet_ve.pdf). Modern bir birey, teknolojiyle o denli bağımlı bir hale gelmiştir ki topluma yeni ufuklar açan akılcılık geri planda kalmıştır. Bookchin'e (1996:25) göre "Teknoloji insanlığın bir uzantısı olmaktan çıkmış; insanlık teknolojinin bir uzantısı haline gelmiştir" Bu durumda, teknoloji insanlar için araç olmaktan çıkmış amaç haline gelmiştir ve yalnızlaşma, yabancılaşma gibi olumsuz durumlar da bunun sonucu olarak ortaya çıkmıştır (Turan, 2002:271-281). Davutoğlu'na (1995:15) göre araç-merkezli iletişim, iletişim kanallarının fazlalaşmasına neden olmuş böylelikle insan-merkezli iletişimin ilişki biçimleri ortadan kalkarak insanın yalnızlık dünyasının da sınırları genişlemiştir.

Sosyal ağlar, gençler ve yetişkinlerin daimi olarak takip ettikleri sosyal medya mecralarıdır. Genç yetişkinlerin \%82'si bu sitelerin yöneticisi iken, $\% 73$ oranında genç ise bu ağlarda vakit geçirmektedir (Cornejo vd, 2013:889). Boyd(2007:21), günümüz toplumunda, ailelerin ulaşım vb sorunlardan dolayı gençleri çok fazla bir yerlere göndermemeleri evin kurallarının ise yine aileler tarafından koyulması sebebiyle gençler hem evde hem de dişarıda yeterince sosyalleşemediklerini ifade etmektedir. Yine Livingstone (2010:14), ailelerin dışarıda oluşan tehlike ve risklerden çocuklarını korumak amaçlı “ev"lerini çocukların kimliğini ve boş vakitlerini geçirmeleri için oluşturulan bir alan olarak gördüklerini, evi çocuklar için güzel bir ortam haline getirmeye çalıştıklarını ancak sokak kültürünün azalmasıyla medya zengini evlerin oluştuğunun göz ardı edildiğini vurgulamıştır. PadillaWalker (2012:427) Kaiser Aile Kurumun'nun yaptığı araştırmayı çalışmasında yer vermiştir. Araştırmaya göre 8-18 yaş arasındaki gençler eğlence medyasına günde 7.5 saat, haftada ise ortalama 53 saat harcamakta; bu kullanımda ise zamanlarının çoğunu sosyal medyalara ayrılan internet bağlantıları, cep telefonları, IPodlar, MP3 oynatcılar gibi araçlardan elde edilen materyaller bulunmaktadır. Gençler gündelik hayatta yaptıkları birçok aktiviteyi aynı anda yapmaları internet kullanımını cazip hale getirmektedir; bireyler aynı anda Facebook'ta arkadaşları ile görüşürken aynı anda alışveriş yapabilmektedirler böylelikle hem gündemden geri kalmamakta hem de bir yandan tüketebilmektedirler (Kart: 2014:184). Kimberly S. Young'un araştırmaları sonucunda sosyal medya bağımlılığı ile ilgili çeşitli tanı ölçütleri ortaya koymuştur ve bu ölçütler aşağıdaki gibidir:

- $\quad$ "Sosyal medyada yapılacak olan aktivitelerin planlanması, tasarlanması ve sürekli olarak çevrimiçi olma arzusu, bulunma isteği,

- $\quad$ Keyif almak, eğlenmek ve sıkıntıları gidermek için sosyal paylaşım ağlarında

- $\quad$ Sosyal paylaşım ağlarında vakit geçirme ve bulunma sürelerini istem dışı bir şekilde kontrol edememe,

- $\quad$ Sosyal paylaşım ağlarında bulunmama, uzak kalma durumunda bireyin huzursuzluk ve mutsuzluk hissetmesi,

- Başlangıçta planlanandan daha uzun süre paylaşım ağlarında vakit geçirme,

- $\quad$ Gereğinden fazla sosyal paylaşım ağlarında zaman geçirme nedeniyle ailesel, çevresel sorunların yaşanması ve kariyer-eğitim firsatlarının kaybedilmesi,

- Sosyal ağlarda bulunabilme adına başkalarına (aile, arkadaş, psikolog..vb.) yalan söylenmesi amaciyla kullanma" 
Bu bağlamda ilgili ölçütler, sosyal medya' yı "insanı asosyalliğe iten, yalnızlaştıran, bir başına kalmasına neden olan bir ortam” olduğunu ortaya çıkarmış ve Çakır (2014:200) çalışmasında bu durum ile ilgili şu sözlere yer vermektedir:

"Yolları, sokakları, toplu taşıma araçlarını, vapurları, bekleme salonlarını, toplantı ortamlarını, eğitim kurumlarını, devlet kurumlarını ve akla gelebilecek her yeri kaplayan ekranlar, bireysel teknolojik cihazlarla da kişiyi her an kendisi ile başbaşa kalmaktan, kendini dinlemekten alıkoyar, meşgul eder. Diğer insanlarla etkileşimini zorlaştırır. İzleyicilik genel bir role, bir yaşam biçimine dönüşür. Görüntü bağımlılığı tüm bu süreçlerin üstün ürünüdür. Sürekli birilerini izlemekten bunalan birey, artık kendisi de ekranlarda görünmek ister. Bunun özlemini çeker. Çünkü ekranda olmak, herkesin izlediğini düşünmek, tatmin edici bir şey gibi görünür. Ekranda olmak, bir mutluluk vaadi sunar. İlgi çekmek, değer verilmek, anlaşılmak gibi algılanır. Bunlar, bireyin modern hayatta elinden alınmıs, yitip gitmiş önemli insanal ihtiyaçlardır. Toplumsal yaşantıda elde edilemeyen tatmin, ekranlar yoluyla, görünmek yoluyla ikame edilmek istenir. Yeni medya bunu mümkün kılmış ama çok sayıda sorunu da beraberinde getirmiştir."

İnsanların hayatlarını daha fazla kolaylaştırması, yaşam kalitesini arttırması beklenen teknoloji, insanların hayat kalitesini düşürmekte, insanların sözü edilen araçlara sırtlarını dayayarak diğer insanlara kolayca sırt çevirdikleri böylelikle insanlar arasındaki ilişkilerde yabancılaştığı ve bireylerin yalnızlaştığı, çocukların ve gençlerin artık çok daha az sokaklarda olduğu bir yaşam biçimi yarattığını ve bunun adının da "teknolojik yalnızlık" olduğu belirtilmiştir.

Rook (1984) yalnızlığı "bireyin diğerleri tarafindan anlaşılmadığı, onlara yabancı kaldığı ya da onlar tarafından reddedildiği ve/veya özellikle sosyal bütünleşme duygusu ve duygusal yakınlık kurmak için olanaklar sunan, arzu edilen etkinlikleri gerçekleştirmek için uygun sosyal partnerlerin yokluğu durumunda yaşanılan, süreğen duygusal zorlanma" olarak tanımlamıştır. Günay, (2008:98) sosyal/sosyolojik yalnızlıktan "bireyin diğerleri tarafından dışlanmasından, ilişkilerinin bozulması" olarak bahsetmiştir. Peplau ve Perlman (1982:1-18) ise yapılan yalnızlık tanımlarını şöyle değerlendirmişlerdir: ilk olarak, yalnızlık bireyin sosyal ilişkilerindeki yetersizliklerden kaynaklanmakta olduğunu, bireyin sahip olmak istediği ilişki ile sahip olduğu ilişkiyi kıyasladığını, ikinci olarak da yalnızlığın nesnel olan sosyal izolasyondan farklı olduğunu, öznel olduğunu bahsetmektedir. Böylelikle bireyler kalabalıkların arasında bile yalnız olabildiklerinden söz etmişlerdir. Pelling ve White (2009:755-759) ise çalışmalarında gençlerin sosyal ağları kullanmalarındaki temel amaçlarının gençlerin aidiyet ihtiyaçlarının giderilmesi ve başkalarıyla ilişki kurma ihtiyaçlarının karşılanması olduğunun altını çizmişlerdir. Bowman'e göre, bireyi yalnızlığa götüren üç sosyal durumu şöyle sıralamaktadır: birincil grup ilişkilerin parçalanması, aile hareketliliğinin artması ve sosyal hareketlilikte meydana gelen artış (Bowman, 1995:195). Riesman, modern toplumdaki bireylerin 'öteki yönelimli' hale geldiğini, yani davranışlarını sürekli olarak kişilerarası çevreye uyarlamaları gerektiğini savunmaktadır. Bu durum bireyleri içsel benliklerinden, duygularından ve isteklerinden uzaklaştırmaktadır. Böylece, birlikte 'yalnız kalabalıklar' oluşturmaktadırlar (Riesman, 1961, s. 38).

$\mathrm{Bu}$ bağlamda, internet ve sosyal ağların kullanımındaki artışın, kişilerin kendilerini ait hissetme isteği ve ilişki kurma arzusuna bağlı olduğu söylenebilinmektedir. Yapılan araştırmalar, aile içi ilişkilerin zayıflamasıyla beraber kişilerin sosyalleşmek, iletişim kurmak amacı ile sosyal ağları tercih ettiklerini, bu ihtiyaçlarını internete girerek karşıladıklarının altını çizmektedir (Bayraktutan, 2005). Esen ve Siyez'in (2011:128) de çalışmalarında belirttikleri gibi yalnızlık, cinsiyet, aileden alınan sosyal destek, akademik başarı gibi 
etkenlerin bireylerin internet ve sosyal medya bağımlılığı üzerinde etkili olduğu bilinmektedir.

Türkiye'de internet ve buna bağlı olarak sosyal medya bağımlılığı üzerine yapılan araştırmalar incelendiğinde, yalnızlık düzeyindeki artış ile internet ve sosyal medya bağımlılığındaki rakamsal anlamdaki büyüme arasında paralel bir artış olduğu görülmektedir. Hızla ilerleyen dijital dünyada, insanın uyum sürecine ayak uyduramaması, kişinin dijital ağları amaç haline getirmesi, yaşadığ 1 gerçek dünya ve toplumla arasına uçurumlar girmesi sonucu birey yalnızlığa ve çaresizliğe sürüklenmektedir (Mercan, 2010:11). Bu bireyler, ruhsal yalnızlıklarının yanında çevrelerine ve hatta ailelerine bile yabancılaşarak, kalabalıklar içinde yaşayan fakat aynı zamanda yalnızlaşan toplumları meydana getirmektedirler. Uzmanlar, ebeveynlerin de kendileri gibi çocuklarını da internetin başına terk ettiklerini ve aile bireylerinin kendi evlerinde birbirleriyle konuşmadıklarını bu nedenle birbirlerinden uzaklaşarak yabancılaştıklarını vurgulamışlardır ( $\underline{\text { www.oku.on5yirmi5.com }) . ~ B u ~ d u r u m u n ~}$ sonucunda ise psikolojik ve sosyal sorunlar ortaya çıkmakta; birey kendisini oluşturduğu sanal dünyanın içine hapsederek toplumdan soyutlanmaktadır. Sosyal medya ağlarının sunduğu çevrimiçi oyunlar ve eğlenceli içeriklerin bağımlılık yaptığı ve çocuk ve anne arasında bile yabancılaşmaya sebep olduğunu gösteren örneklerden bir tanesi de ABD'de bir annenin Facebook ağı üzerinden FarmVille oynarken çocuğunun sürekli ağlayıp onunla ilgilenmesini istemesi üzerine oyunu yarıda kesen ve böylelikle oyunda gelmesi gereken seviyeye ulaşamaması üzerine çocuğunu camdan atarak cinayetten tutuklanmasıdır (Martinez, 2010).

Aristo'nun ifadesiyle "insan sosyal bir varlıktır." Sosyal ilişki kurmak ve bu ilişkiyi sürdürmenin çok daha zor bir hale gelmesi, sosyal izolasyon modern çağın sorunlarından biridir. $\mathrm{Bu}$ durum beraberinde bireyselleşme gibi sorunları getirmektedir. İnsanlar artık kendine bağımlı hale gelmekte ve sosyal ilişkiler kurabileceği ya da geliştirebileceği, toplumsal mekanlardan kendini izole etmektedir. Sosyal paylaşım ağlarının kullanım oranındaki artış, bu durumu tetiklemektedir. Elbette sosyal bağların tümüyle bozulduğunu söylemek doğru değil; fakat bireysel yaşam biçimi toplumun karakterini değiştirmiştir. $\mathrm{Bu}$ durumun etkilerini gündelik yaşantılarımızda, insanlar arasındaki ilişkilerde ve genel olarak sosyal çevrede fark etmek mümkündür. Geçmişte insanlar, istikrarlı bağlara sahipken (evlilik, aile, komşuluk, iş ilişkileri vb) günümüzde nispeten kısa süreli ilişkiler kurulmaktadır ve insan ilişkilerinde bağlar çok zayıflamıştır (Hortulanus, Machielse\&Meeuwesen, 2006:4).

\section{AMAÇ VE YÖNTEM}

Sosyal paylaşım ağlarının toplum üzerindeki etkisi ile ilgili pek çok araştırma yapılmıştır. Bu konudaki genel kanı, neredeyse sosyal paylaşım ağlarına bağlı olarak yaşayan bireylerin kendilerine ve dış dünyaya yabancılaşmaları ve yalnızlaşmaları yönündedir. $\mathrm{Bu}$ çalışmanın amacı reklamlardaki bu konumlandırmanın bireyin dijitalleştikçe yalnızlaştığı düşüncesine etkisinin önemini vurgulamaktır. $\mathrm{Bu}$ amaç, yediden yetmişe hitap eden ürün yelpazesiyle küresel bir marka olan Coca Cola'nın yurtdışında yayınlanan reklam filmi üzerinden açıklanmaya çalışılmıştır. Örnek reklam filmi olarak Coca Cola markasının seçilme nedeni marka olarak küresel bir bakış açısı yansıtması, çocuklar, gençler, yaşlılar tarafından marka bilinirliliğinin yüksek olması, geniş bir tüketici kitlesine sahip olmasıdır. Göstergebilimsel olarak çözümlenen reklam filmi, kadın, erkek, çocuk, orta yaşlı, genç, toplumun her kesiminden ve her yaştan bireylerin yer alması bakımından seçilmiştir. Çözümleme düz anlam/yan anlam düzeyinde, gösteren-gösterilen ilişkisi içerisinde gerçekleştirilmiştir.

F. de Saussure, göstergebilimi "göstergelerin toplum içindeki yaşamını inceleyecek bilim” olarak tasarlamıştır (Saussure, 1983: 13). Saussure göstergebilimin toplumsal işlevini, 
Peirce ise mantıksal işlevini vurgulamaktadır. Ama göstergebilimin bu iki yönü arasında sıkı bir bağlılaşma vardır. S'miologie ve sémiotique sözcükleri bugün artık aynı alanı kapsamaktadır. Göstergebilim ilkelerinin temel kavramlarından olan gösterge ile yarışan şu terimler de mevcuttur: belirtke, belirti, görüntüsel gösterge, simge, alegori, v.b. Tüm göstergebilim eserlerinde en yaygın biçimiyle adlandırılan göstergeyi tanımak için öncelikle nasıl tanımlandığına bakmak gerekmektedir (Karc1, 2017:?) Saussure' ün terimleri arasında gösterilen ve gösteren göstergenin oluşturucularıdır. Dilsel gösterge, bir şeyi ve bir ismi değil; bir kavram ve bir ses-imgesini bir araya getirmektedir. Bu sözü edilen materyal bir ses, yalnızca fiziksel bir şey değil, sesin psikolojik anlamda basılmış hali, duyularımız üstünde bıraktığı izlenimdir (Saussure, 1983: 642). Göstergenin işlevi, bildiriler aracıllığıyla düşünceler iletmektir. Bu iletim işlemi bir nesne, yani kendisinden söz edilen bir şey ya da gönderge; göstergeler ve bundan dolayı bir düzgü, bir iletim aracı ve de doğallıkla bir yayıcı ile bir alıcı içermektedir (Guiraud, 1990: 9). Saussure, gösterilenin öz niteliğini, kavram terimini kullanarak belirtmiştir (Saussure, 1983: 650).

Gösterilen üstünde hep bir hakimiyeti var gibi görünen gösteren, Saussure' ün gösterilen ile ikisi arasında sağladığı dengeleyici yaklaşım sayesinde demokrasiye kavuşmuştur. Gösteren, de tıpkı gösterilen gibi göstergeyi oluşturan diğer kavramdır. Göstergenin duyulan yani ses imgesidir. Akla ilk gelen görüntüsüdür (Saussure, 1983: 651; Barthes, 1993: 46).

Roland Barthes anlamın yananlam ve düzanlam düzlemini ise şu şekilde açıklamıştır:

Hjemslev' in gösterge, gösteren ve gösterilen arasındaki anlamlamaya dair bakış açısından yola çıkılacak olunursa; her anlamlama dizgesinin bir anlatım düzlemi (A) ile bir içerik düzlemi (İ) kapsadığını ve anlamlamanın bu iki düzlem arasındaki bağlantıya (B) eşit olduğu (A B İ) açıklaması hatırlanır. Burada iç içe geçmiş, aynı zamanda da birbirinden ötürü sapma ve kayma sergileyen iki anlamlama dizgesi ortaya çıkacaktır. Bunlar düzanlam ve yananlam dizgeleridir. Bunlar bir yandan birbirlerine bağlıyken bir yandan da iki karşıt bütün olarak görülebilirler: İlk dizge (düzanlam), ikincinin (yananlam) anlatım düzlemi ya da göstereni olur. Yananlam gösterilenine gelince, hem genel, hem bütünsel, hem de dağınık bir özellik taşımaktadır. Bu gösterilenler de kültürle, bilgiyle, tarihle sıkı bir ilişki içindedir. Yananlam gösterge dizgesinde, ikinci dizgenin gösterenleri birinci dizgenin göstergelerinden oluşmaktadır (Barthes, 1993: 72).

\section{BULGULAR}

\section{Coca cola "Sosyal Medya" temalı reklam filmi:}

Reklam filmi 1:50 saniye süresince devam etmekte ve 50 sahneden oluşmaktadır. Reklam, akıllı telefonların üzerindeki sosyal medya platformlarının tıklanmasıyla başlamaktadır. (Youtube, instagram, facebook, twitter). Dış ses ise sosyal medyanın harika olduğunu ve bizi dünyaya ve sevdiğimiz insanlara bağladığını ifade ederek sosyal medyanın pozitif yönelerini sayarak ve sosyal medyada ne gibi anların paylaşılabildiğinden bahsetmektedir. Diğer bir yandan sosyal medya insanları dünyadan uzakta biraktığ zamanların olduğunu dile getiriyor. Buna "dur" demek için Coca Cola'nın "sosyal medya koruyucusunu" ön plana çıkardığını ve bunun nasıl çalıştığını anlatır. Burada bireylerin boyunlarına takılmış kırmızı renkte üzerinde Coca Cola yazan "koruyucu" kişileri kendilerinin yalnızlaştıran sosyal medyadan başlarını kaldırıp bulundukları çevrenin farkına varmalarını sağlamaktadır. Herkese de bu "koruyucuyu" almasını tavsiye ederek reklamı bitirir. (https://www.youtube.com/watch?v=RiUNAjaeAFc)

\subsection{Toplumsal Yalnızlık Göstergelerinin Düzanlam Düzeyinde Çözümlenmesi}


Gösterge biliminin temelinde bulunan gösterge=gösteren/gösterilen yapısının gösteren kısmı düz anlamı temsil etmektedir. Bu sebeple, analizin bu bölümünde reklam videosunda yer alan gösterenler incelenecek ve düz anlamları ortaya konulacaktır. Reklamın başında bir akıllı telefon ekranı üzerinde çeşitli sosyal medya platformları ve farklı uygulamaların imgeleri görülmektedir. Bunlardan Facebook, Youtube, twitter, instagram uygulamaları bir parmak ucuyla seçilerek tıklanmaktadır. Reklamın bir sonraki sahnesinde Dubai'de deniz kenarında bulunan Burj El-Arab binası, deniz, güneş ve çeşitli insanlar ön plandadır. Genç bir adam elindeki akıllı telefonuyla ilerlemektedir. Bir diğer karede, baş başa yemeğe çıkmış bir çift yemek masasında oturmuş ellerindeki akıllı telefonlarına bakmaktadırlar. Yine bir başka karede, kahvaltı masasında toplanmış bir aile bulunmaktadır. Bu ailede eşler, bir çocuk ve bir bebek birliktedirler. Bunlardan baba yani erkek eş akıllı telefonuna bakmaktadır. Bebek ise bir eliyle babasının kolunu çekiştirmekte, eş ve diğer çocuk ise babaya bakmaktadırlar. Bir başka karede ise, dört arkadaş bir yemek masası etrafında toplanmış, sofrada bulunan içi yemek dolu tabaklarının akıllı telefonları ile fotoğrafını çekmektedirler. Diğer karede ise, iki kız çocuğu oturma odasında yere oturmuş akıllı telefonlarında bulunan sanal hayvanlarını beslerken, bu sırada evlerinde bulunan kedi önlerinde dolaşmaktadır. Bundan sonraki karelerde yolda yürümekte olan çeşitli insanların etraflarına bakmadan akıllı telefon ekranlarına odaklandıkları görülmektedir.

Tam bu anda ekrana kırmızı bir platform üzerinde "Coca Cola Analog Lab" yazısı belirmektedir. Hemen ardından "Social Media Guard" yazısı belirir. Social Media yazısı siyahi yan taraftaki logo ve guard yazısı kırmızıdır. Guard yazsındaki D, iki nokta ile ayrılarak gülücük ikonuna dönüşür. Bu ifadenin hemen ardından tüm ekranı kaplayacak şekilde kırmızı renkte içinde Coca Cola logosu geçen kırmızı bir ikon belirir. Karşılıklı oturmuş bir kadın ve erkek ellerinde bulunan akıllı telefonlarına dalmışken bir anda boyunlarına geçen kırmızı ikonla birbirlerine bakmaya başlarlar. Bu kırmızı ikon boyunlarına dik bir yaka şeklinde oturtulmuştur. Ellerindeki telefonlarını yavaşça aşağıya indirip göz temaslarından uzaklaştırırlar. Dubai'de deniz kenarında olan çocuğun boynunda da yine aynı kırmızı yakanın belirmesiyle akıllı telefondan başını kaldıran genç arka planda kalan güneşi görmektedir ve gözünde güneşin yansıması belirir. Masada önce baş başa bulunan çiftin boyunlarında da bu kırmızı Coca Cola yakası belirdikten sonra gözlerini telefonlarından uzaklaştırıp birbirlerine bakarlar ve yüzlerinde bir tebessüm belirir. Kahvaltı sofrasında ailesi ile beraber olan adam boynunda beliren Coca Cola yakası ile birlikte telefonundan uzaklaşır, ailesiyle birlikte olmaya başlar ve gülümser. Bir masa etrafında yemekte olan arkadaşlar boyunlarında beliren Coca Cola yakası ile birlikte telefonundan uzaklaşır, ailesiyle birlikte olmaya başlar ve gülümser. Bir masa etrafında yemekte olan arkadaşlar boyunlarında beliren Coca Cola yakası ile birlikte yemeklerinin fotoğraflarını çekmekte oldukları telefonlarından uzaklaşıp birbirlerine bakmaya başlarlar ve yüzlerinde bir gülümseme oluşur. Sanal hayvanları besleme oyunlarını oynayan çocuklardan birinin boynunda beliren kırmızı yaka ile gözlerini ekrandan uzaklaştıran kız çocuğu kendi evcil hayvanının farkına varır. Tün bunların üzerine "Social Media Guard" yazısı tekrar belirir. Son olarak, yemek yiyen arkadaşlar boyunlarındaki kırmızı yaka ile yüzlerindeki gülümseme ifadesi ile Coca Cola içeceğini içmeye başlarlar. Yakın plandaki Coca Cola içeceğinin ardından "Şimdi kendininkini al" yönergesi dış ses’ten gelir. Reklamın sonunda kırmızı fonda Coca Cola logosunun birbirine Coca Cola içeceği uzatan iki el şeklinde belirdiği ve Coca Cola ikonunun yanında "Share a real moment with Coca Cola", "Coca Cola ile gerçek bir an paylaş" sloganı belirmektedir.

\subsection{Toplumsal Yalnızlık Göstergelerinin Yananlam Düzeyinde Çözümlenmesi}

Göstergeyi oluşturan ikinci öğe gösterilenin temsil ettiği yan anlamlara bakıldığında ilk başta görselde akıllı telefon üzerindeki sosyal medya uygulamalarının logolarına tıklaması dış sesin de belirttiği üzere insanların sosyal medya ile dünyaya bağlandıklarını ifade 
etmektedirler. Burada dış sesin de belirttiği gibi sosyal medyanın olumlu etkisi ön plana çıkarılmaktadır. Art arda sıralanan karelerin ortak yanı farklı ortamlarda bulunan bireylerin ellerinde bulundurdukları akıllı telefonlarına odaklanarak yani sosyal medya platformlarına dalarak bulundukları ortamdan ve gerçek dünyadan koptukları, bu doğrultuda kalabalıklar içerisinde yalnızlaşarak çevrelerine yabancılaştıkları görülmektedir.

Dubai'de deniz kenarında olan genç, bulunduğu doğal güzelliğin farkında değilken, baş başa romantik bir akşam yemeğine çıkmış çift birbirleri ile ilgilenmek yerine sosyal medya hesaplarına dalmışlardır. Öte yandan, sıcak bir aile kahvaltısı ortamında bulunan adam eşinin ve çocuklarının kendisine gösterdikleri ilgiyi görmezde gelirken, hep birlikte yemek yiyen arkadaşlar birbirleri ile iletişim kuracaklarına önlerinde duran yemeklerin fotoğraflarını çekip sosyal medya ağlarında paylaşarak sanal bir iletişsimin içinde olmayı tercih etmişlerdir. Son olarak, iki küçük kızın oturma odalarında onlardan ilgi bekleyen sevimli kedileri yerine sosyal medyada besledikleri sanal hayvanları ile ilgilendikleri göze çarpmaktadır. Görüldüğü gibi, tüm bu insanlar sosyal medya ağları yüzünden bulundukları ortamdan koparak gerçek dünya ile bağlarını da koparmaktadırlar. Bunların yanı sıra, dış ortamlarda yürümekte olan ya da arabalarına binmekte olan insanların asıl yapmakta oldukları işlerden koparak durup sosyal medya hesaplarına odaklanmaları dış dünya ile bağlarını kestiklerini göstermektedir. Coca Cola tam bu noktada Analog Lab birimi aracılığıyla sunduğu sosyal medya koruyucusunu devreye sokmaktadır. Yazıda beliren Guard (koruyucu) sözcügünün GUAR:D şekline dönüşerek bu insanları yeniden sıcak bir iletişim ortamına sokacağının işareti verilmektedir. Bir sonraki sahnede ortaya çıkan Coca Cola logolu kırmızı ikonun bahsi geçen ortamlarda bulunan insanların boynuna geçerek kırmızı bir yaka belirmektedir. Coca Cola markalı Elizabeth tarzı yaka, bir köpeğin saldırmasını engellemek amacıyla boynuna geçirilen koruyucu ile özdeşleşmektedir. Burada yapılmak istenen şey kişilerin aşağıya bakma eğilimini engelleyerek göz hizasında tüm ufkunu görecek şekilde bir görüş açışı yaratmaktır

(https://books.google.com.tr/books?id=a7L1CwAAQBAJ\&pg=PT108\&lpg=PT108\&dq=coca + cola + analog + lab\&source $=$ bl\&ots $=w g X 3-$

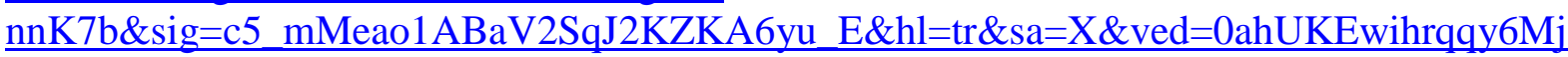
aAhVFliwKHXfmCnoQ6AEIOTAF\#v=onepage $\& \mathrm{q}=\mathrm{coca} \% 20 \mathrm{cola} \% 20$ analog\%20lab $\& \mathrm{f}=\mathrm{fals}$ e.)

Farklı ortamlarda bulunan bu kişiler gençlik, canlılık ve enerjisi temsil eden kırmızı renkte olan yakayı boyunlarına geçtiği andan itibaren başlarını yukarıda tutmak zorunda kalmış, böylelikle çevresinde ne olup bittiğinin farkına varmış ve birbirleri ile etkileşime geçme firsatı yakalamış, romantik bir akşam yemeğine çıkan çift başlarını kaldırmak zorunda kalıp tekrar birbirlerini görebilme şansını elde etmişlerdir. Tıpkı bu insanlar gibi ailece kahvaltı sofrasında bulunan adam yine başını takip ettiği sosyal medya platformlarından kaldırmak zorunda kalıp güzel ailesinin farkına varmıştır. Çocukları ve eşi ile güzel ve mutlu dakikalar geçirmektedirler. Yemeklerini fotoğraflarını çekip sosyal medya ağlarında paylaşabilmek uğruna birlikte geçirdikleri anın tadını çıkaramayan arkadaşlar yine bu sosyal medya koruyucusu sayesinde bir arada olduklarının farkına varmış ve mutlu olmuş, sosyal medya platformlarını sanal hayvanlarını besleyen küçük kızlar bu koruyucu sayesinde evlerinde bulunan kendi kedilerini görebilme firsatını yakalamışlardır.

Tüm bunları özetleyen son sahnede boyunlarında sosyal medya koruyucusu sayesinde mutlu olan insanların beraberinde içtikleri Coca Cola içeceği ile birlikte mutluluğa kavuştukları işaret edilebilmektedir. Daha önce "Tadını çıkar", "Mutluluğa kapak aç" gibi sloganlarıyla tüketicilerin duygularına dokunmayı hedefleyen Coca Cola yine insanların sosyal medya yüzünden yalnızlaşması ve çevrelerine yabancılaşması sebebiyle mutsuzlaşan insanların duygularına temas etmektedir. Yani reklamda, sosyal medyanın getirdiği 
olumsuzluğa ve iletişimsizliğe bir dur demektedir. Gençlerin telefonlarına bakmaktan hayatı yaşayamadığ1 fikrinden yola çıkan firma, "Sosyal Medya Koruyucusu"nu üretmiş. Sosyal Medya Koruyucusu, sosyal medyayı korumak için değil, insanları sosyal medyadan koruyor. Boyuna geçirilen kocaman bir koniden ibaret olan koruyucu, kullanıcıların konuşurken, yemek yerken, bir randevudayken telefonuna bakmasını engelliyor

\section{SONUÇ}

Toplumsal temaslar, bireylerin kişisel ve toplumsal refahı açısından son derece önemlidir. Sosyal temas, bireyin temel ihtiyaçlarından biri olmakla birlikte, toplumdaki bireylerin birbirleriyle entegrasyonu ve bağlantı kurması açısından gereklidir. Modern batı toplumlarında bireyselleşme ve sosyal parçalanma süreçleri nedeniyle, sosyal temaslar giderek artan bir baskı altına girmiştir. Bireyler arasındaki sosyal ilişkiler bağlamında ele alındığında, giderek sosyal ilişki kurmak ve onu korumak zorlaşmaktadır. Dolayısıyla, giderek daha fazla insan sosyal olarak izole olmakta, yalnızlık duyguları hissetmekte ya da toplumsal hayata karışma noktasında sıkıntı yaşamaktadır. Sosyal medya platformları, bu noktada sosyalleşmeyi kolaylaştırma noktasında, kullanıcılara zengin bir dünya sunmaktadır. Sosyal medya ortamlarında zaman-mekan birliğinin önemini yitirmesi, dünyanın bir ucuyla iletişim kurulmasına olanaklı hale getirme, bilgiye ulaşmayı kolaylaştırma, küreselleşme, kurulan sosyal ilişki ağının genişlemesi gibi avantajlar sunarken; bireyin sanal dünyayı gerçek hayatta kurulan ilişkilere tercih etmeye başlaması gibi önemli sorunları da beraberinde getirmektedir.

Schools.com internet sitesinde yer alan infografiğe göre insanların \%24'ü yaşadiğı an ve deneyimlerin tadını çıkartmak yerine sosyal ağlarda yaşadığını ve tecrübelerini paylaşma çabası içerisine girmektedirler. Bu durum ise kişilerin anı yaşamak yerine paylaşmayı tercih ettiklerini göstermektedir. İnfografikteki bilgilerde, insanların her gün Facebook'ta 10,5 milyar dakika geçirdiğini ve mobil girişleri içermeyen sayının yaklaşık 19,963 yıla tekabül ettiği belirtiliyor (Sanlav, 2014:89).

Bu bağlamda, Coca Cola'nın 'başınızı sosyal medyadan kaldırın ve dünyaya bakın' temalı reklam filmi; giderek akıllı telefon, laptop ve tablete bağımlı, sosyal medya figürleri haline gelen insanları reklam filminin içine alarak bireylere dışarıdan nasıl göründüklerini göstermeye çalışmaktadır. Reklam da yer alan çocuklardan, gençlere, yetişkinlere kadar her bir birey yaşadıkları hayatı, anı ve yanlarındaki kişileri bir kenara bırakıp sosyal medya platformlarında olmaktan büyük zevk duymakta ve geçirdikleri zamanın tadını çıkaramamakta veya beraber olduğu insanlarla yan yana olmalarına rağmen iletişime geçmeden sadece fiziki birliktelikler yaşamaktadırlar. Coca Cola, insanların akıllı telefonlarının bataryaları bittiğinde insanların hayata gerçek anlamda döndüklerini baz alarak onları zorunlu olarak ekranlardan başlarını kaldırmalarını sağlayan koni ile dünyayı görmelerini sağlamaktadır. Bu reklam, bireyler arasında iletişimin sanal olmasından ziyade yüzyüze olması gerektiğini, unutulmaya yüz tutmuş hayatın ve anın tadını çevremizdekilerin farkına vararak çıkarıldığı zamanları tekrar hatırlatmaktadır. "Sosyal Medya Temalı" reklam, "kafamızı kaldırıp dünyaya bakma" konusunda mesaj vermekte ve modern dünyanın yalnız insanları arasında farkındalık yaratmaktadır. Reklam filmi, henüz Türkiye'deki kitle iletişim araçlarında görülmemekle beraber yalnızca yabancı kanallarda ve internet üzerinden İngilizce olarak yayınlanmaktadır. Bu çalışma ile birlikte Türk markaları da bireylerin iletişimi kapsamında ve "Sosyal Medya Temalı" reklamlar yayınlayarak bireylerin "gözlerini dünyaya çevirmeleri” bağlamında farkındalık yaratmaya katkıda bulunabilirler. 


\section{KAYNAKÇA}

Avc1, A. (2017). “Her Zaman Çevrimiçi”’Olmak, Epôke Sosyal Bilimler Dergisi.

Bayraktutan, F. (2005). Aile içi İlişkiler Açısından İnternet Kullanımı. Yayınlanmamış Yüksek Lisans Tezi, Istanbul Üniversitesi, Istanbul.

Bookchin, M. (1996). Ekolojik Bir Topluma Doğru. Istanbul: Ayrıntı Yayınları.

Cabral, J. (2011). "Is Generation Y Addicted to Social Media?", The Elon Journal of Undergraduate Research in Communications, Vol:2, No:1.

Cornejo, R. Tentori, M., Favela, J. (2013). "Enriching in-person encounters through social media: A study on family connectedness for the elderly." Human Computer Studies, Vol. 71.

Çakır, M. (2014). Görsel Kültür ve Küresel Kitle Kültürü. Ütopya Yayınevi: Ankara.

Çakır, M. (2013). Medya ve Modernlik. Parşömen Yayıncılık: Istanbul.

Çizmeci, E. (2015). Yeni Medya ve Serbest Zaman. İletişim Çalışmaları, Istanbul: Derin Yayınları.

Davutoğlu, A. (1995). “Derinliğini Kaybeden İletişim” İzlenim Dergisi, Say1:30.

Eldeniz, L. (2010). “İkinci Medya Çağında Etkileşimin Rolü ve Web 2.0”, İkinci Medya Çăgında İnternet, 2010.

Ellison, D. (2012). Sociality Through Social Network Sites. The Oxford Hnadbook of Internet Studies, Oxford: Oxford University Press.

Giddens, Anthony. Modernliğin Sonuçlarl, Çev. Ersin Kuşdil. Istanbul: Ayrıntı Yayınları, 2012

Giddens, A; Pierson, C. (2001). Modernliği Anlamlandırmak, Çev. Serhat Uyurkulak ve Murat Sağlam. Istanbul: Alfa Kitabevi.

Günay, M. (2008). "Yalnızlık ve Birliktelik Arasında İnsan İlişkileri” Aratos Dergisi, 2008 http://docplayer.biz.tr/61082881-Yalnizlik-ve-birliktelik-arasinda-insan-iliskileri-1yrd-doc-dr-mustafa-gunay.html

Harvey, D. (1999). Postmodernliğin Durumu. Metis Yayınları, İstanbul

Kart, E. (2014). "Boş Zamanın Çoklu Tüketim Mekanı Olarak İnternet ve Yeni Yaşam Tarzlarının İnşası". Global Media Journal.

Kaya. A. (2013). "Sosyal Paylaşım Ağlarının Kişilerarası İletişim Sürecine Etkisi bağlamında Facebook", Sosyal Medya Araştırmaları 1: Sosyalleşen Birey Iç̧inde, Metis Yayınları, Istanbul.

Kuşay, Y. (2010). “Sosyal Medyanın Gücü ve Uygulama Örnekleri”, İkinci Medya Çağında Internet,

Küçüksaraç, B. (2013). Prosumer Kadınlar ve Kendin Yap Bloglarında Üretim ve Tüketim Pratikleri, Yeni Medya Araştırmaları: Kavramlar, Uygulamalar, Araştırmaları Literatürk Academia: Istanbul.

Livingstone, S. (2010). "From Family Television to Bedroom Culture: Young People's Media At Home Originally published in Devereux, Eoin, (ed.) Media studies: key issues and debates. London, Sage Publications, 2010. 
Pelling, E. L., ve White, K. M. (2009). "The theory o Planned Behaviour Applied to Young People's Use of Social Networking Web Sites", Cyberpsychology\&Behaviour.

Peplau, L. A., Perlman, D. (1982). "Perspectives on Loneliness", Loneliness: A Sourcebook of Current Theory, Research and Theraphy, New York: Wiley.

Torlak, Ö. ve Ay, U. (2014). "Facebook'ta Bulunma Amacı ve Facebook Reklamlarına Duyulan İlgi Arasındaki İlişki”. Anadolu Üniversitesi Sosyal Bilimler Dergisi, Eskişehir.

Tutar, Hasan. (2007). "Katı Olan Her İş Sanallaşıyor veya İşgörenin Artan Yalnızlığı Üzerine: Kuramsal Bir Yaklaşım”, İş, Güç Endüstri İlişkileri ve İnsan Kaynakları Dergisi, Cilt:9, Say1:2.

Turkle, S. (2010). Alone Together. Basic Books: New York.

Özkan, G. Ş. (2014). “Ağ Tabanlı Sahnede Benliğin Sunumu: İdealize Edilmiş Duygular” Yeni Medya Araştırmaları: Kavramlar, Uygulamalar, Araştırmalar, Literatürk Academia: Istanbul.

Wallsten, S. What Are We Not Doing When We Are Online. National Bureau of Economic Research Working Paper Series. http://www.nber.org/papers/w19549.pdf?new_window=1

Yengin, Deniz. (2012). Yeni Medya ve Dokunmatik Toplum. Derin Yayınları: Istanbul.

http://scholar.google.com.tr/scholar_url?url=http\%3A\%2F\%2Fwww.academia.edu\%2Fdownl oad\%2F31332059\%2FDIJITAL_DUNYADA_ZAMAN_yedek2.docx\&hl=tr\&sa=T\& ei=XBzCWraIJpKImgHc4KZg\&scisig=AAGBfm0dJ6NrecrBaxXWc68AayY0Pnfvhg $\underline{\text { \&nossl=1\&ws }=1600 \times 752}(23.03 .2018)$.

http://www.calismatoplum.org/sayi17/yilmaz.pdf (20.03.2018)

http://www.comscore.com (01.04.2018)

https://scholar.google.com.tr/scholar?hl=tr\&as_sdt=0\%2C5\&q=nuray+mercan+dijital+d\%C3 \%BCnya+\&btnG $=(05.04 .2018)$

http://www.bilgiyonetimi.org.cm/pages/mkl_gos.php?nt=426 (10.04.2018)

(http://www.arem.gov.tr/yayin/internet_ve.pdf) (13.04.2018)

(http://optimiseblog.co.uk/a-2013-social-media-report/) (13.04.2018)

(https://www.youtube.com/watch?v=RiUNAjaeAFc) (15.04.2018) 